\title{
Sosiaalilääketieteen tulevaisuudennäkymiä ja -haasteista.
}

\author{
ELINA HEMMINKI
}

Sosiaalilääketieteen yhdistys täyttää tänä vuonna 50 vuotta. Yhdistys ei ole ollut vain paperilla vaan aktiivisesti toimiva. Toiminta on tapahtunut vapaaehtoisvoimin ja pääosin ilman institutionaalista kotia. Tämä on kunnioitettavaa. Yhdistyksessä on edustettuna monta eri tieteenalaa ja lähtökohtaa ja ihmisiä on eri paikkakunnilta ja eri sukupolvista. Yhdistys on pyörittänyt sisällöllisten asioiden lisäksi moninaista yhdistysbyrokratiaa ja rahan hankkimista ja julkaissut tieteellistä lehteä auttaen ja kasvattaen alan tutkijoita. Myös seuraavalle vuodelle yhdistyksellä ja sen jaostoilla on monia suunnitelmia tapahtumiin, tiedotukseen ja kansainväliseen yhteistyöhön.

Yhdistyksen nimi ja sosiaalilääketieteen käsite on ajoittain noussut esiin - ja varmaan näin jatkossakin. Minulle sosiaalilääketiede on ollut hyödyllinen käsite biolääketieteen ja kliinisten tieteiden rinnalla - hyväksyen että määritellyt lähestymistavat eivät ole toisistaan erillisiä: alueet menevät reunoiltaan päällekkäin. Ja toiselta reunalta sosiaalilääketiede menee päällekkäin yhteiskuntatieteiden ja monen muun tieteenalan kanssa.

Nimet eivät kuitenkaan ole yhdentekeviä. Epidemiologinen seura perustettiin 1900 luvun lopulla. Osasyynä oman yhdistyksen eikä sosiaalilääketieteen yhdistyksen jaoston perustamiseen lienee ollut, että kaikki epidemiologit eivät mieltäneet, että tautiepidemiologia ja biomarkkeritutkimus voisivat kuulua sosiaalilääketieteeseen. Yliopistoissa nimeä sosiaalilääketiede ei enää juuri näe; kansanterveystiede (public health, community medicine) ovat tavallisempia.

Ranja Aukeen (1) väitöskirjassa yksi empiirinen aineisto oli hänen yhdistyksen jäsenille tekemänsä kyselytutkimus. Aukeen mukaan sosiaalilääketieteen arvoiksi sanottiin yhteiskunnallisen oikeudenmukaisuuden ja tasa-arvon aatteet. So- siaalilääketiede määriteltiin: "terveyden, sairauden ja yhteiskunnan välisiä yhteyksiä tutkiva tiede."

Sosiaalilääketieteellinen Aikakauslehti on vanhempi kuin yhdistys. Lääkäriliitto julkaisi sitä ensin 1960-luvun alkupuolella ja 1960-luvun lopussa vastaperustettu SLY otti lehden julkaisemisen itselleen Lääkäriliiton luovuttua siitä. Suomenkielisen lehden tarpeellisuutta on aika ajoin kyseenalaistettu, erityisesti lääketieteen edustajien toimesta. On kysytty, onko kommunikointi muiden maiden tieteentekijöiden kanssa oleellisempaa (siis englannin kieli) vai kotimaiseen keskusteluun ja ajatteluun suoraan vaikuttaminen (siis suomen kieli).

Riikka Lämsän ja Veli-Matti Partasen artikkelissa pohditaan sosiaalilääketieteen määritelmää ja sen tulevaisuutta (2). Kirjoittajat ottivat yhteyttä Aukeen (1) identifioimaan 12 merkittävään sosiaalilääketieteilijään ja kysyivät, mitä sosiaalilääketiede heidän mielestään on, mistä se on tulossa ja mihin menossa. Kuudella vastanneella oli jossain määrin erilaiset määritelmät sosiaalilääketieteelle, mutta arvoista oli yhtenevämpi käsitys: sosiaalilääketiedettä kuvaa pyrkimys terveyden edistämiseen, oikeudenmukaisuuteen ja tasa-arvoon ja se pitää sisällään sosiaalisen vastuun huono-osaisista. Kirjoittajat kysyvät, mitkä ovat ne yhteiskunnalliset ja globaalit ilmiöt, epäkohdat ja vahvuudet ja sosiaalilääketieteen tutkimus ja vaikuttamistavat, jotka vievät meidät "sosiaalilääketiede 2.0:aan" (uuteen ja parannettuun versioon sosiaalilääketieteestä).

\section{YHDISTYS HUOMENNA}

Seuraavassa kuvaan ajatuksiani sosiaalilääketieteen tulevaisuudesta kahden eri olettamuksen perusteella. Ensimmäisen olettamuksen mukaan maailma menee suunnilleen nykyisellä tavalla ja 
nykyisyydestä ja menneisyydestä voi ennustaa tulevaisuutta. Toisen olettamuksen mukaan ilmaston lämpeneminen ja muut ympäristökysymykset muuttavat Suomen, Euroopan ja koko maailman toiseksi. Varmuudella ei voi sanoa, kumpi vaihtoehdoista toteutuu. YK:n alainen kansainvälinen ilmasto paneelin IPCC raportin (3) mukaan nykymenolla kriittinen 1.5 asteen lämpeneminen tapahtuu vuonna 2040, siis kahdenkymmenen vuoden kuluttua. Siksi nykyistä huomattavasti rajummat päästöleikkaukset ovat tarpeen kiireellisellä aikataululla. Jos ennusteet fyysisen maailman muuttumisesta pitävät paikkansa, myös sosiaalinen maailma muuttuu radikaalisti - ja sen mukana sosiaalilääketieteen tehtävä. "Ilmaston muutoksen mukana muuttuu kaikki".

Jos maailma menee suunnilleen nykyisiä kehityskulkuja seuraten, mitkä ovat sosiaalilääketieteen alueet ja tehtävät? Tutkimusmenetelmät kehittyvät ja kehityksen seuraaminen kuulunee sosiaalilääketieteilijöiden toimenkuvaan jatkossakin. Monitieteisyyden haittapuoli on moninainen käsitteistö ja moninaiset lähestymiskulmat. Sosiaalilääketieteilijän olisi hyvä ymmärtää useita "puhekieliä". Maailma on menossa yhä kansainvälisemmäksi. Tulevaisuudessa muualla tapahtuvaan tutkimukseen ja toiminnan seuraaminen ja siihen osallistuminen on entistä tärkeämpää. Tutkimus ja muu toiminta tarvitsee resursseja. Niiden puolesta puhumisen tärkeys ei tulle vähenemään. Passiiviset raha-anomukset ja kohteliaat keskustelut yliopistojen ja tutkimuslaitosten sisällä eivät riittäne.

Sitä, mihin suuntaan sosiaalilääketieteen tutkimusta tulisi painottaa sisällöllisesti, on vaikeampi määrittää. Kukin näkee oman kiinnostuksen kohteen tärkeänä ja ulkopuoliset tahot säätelevät tutkimusta rahoituksella ja toimintamahdollisuuksilla. Tutkimuksessa antaisin paljon sananvaltaa tutkijoille: he ovat hyvässä asemassa näkemään, mikä on tärkeätä myös tulevaisuudessa. Yksittäisen tutkimuskohteen valinta ei ole ratkaisevaa. Tärkeintä on, että on kriittisesti ajattelevia, hyvin verkottuneita tutkijoita, jotka osaavat lukea ja tuoda tiedon muille hyödynnettäväksi. Klaus Mäkelä, paljossa mukana ollut sosiologi sanoi aikanaan: "Eivät päätöksentekijät tarvitse hyviä tutkimuksia, he tarvitsevat hyviä tutkijoita.”

Oma listani tärkeistä tutkimusalueista sisältää mm. seuraavia. Tautien etiologisessa tutki- muksessa on edelleen tärkeätä selvittää, mitkä ovat tärkeimmät terveyttä uhkaavat ja suojaavat tekijät tänä päivänä, kussakin maassa, alueella, väestöryhmässä ja mitkä niistä ovat hallinnollisilla päätöksillä muutettavissa. Lisäksi selvitystä kaipaa, miten tämä skenaario muuttuu ilmaston muutoksen myötä (olettaen että ilmaston muutos rajoittuu lämpenemiseen). Terveyden edistämisessä makrotason tekijät terveyden säätelijänä kaipaavat tutkimusta: millä tavoin maailmantalous, raha ja yritykset säätelevät terveyden kannalta tärkeitä asioita ja kuinka niihin voi terveyttä edistävästi puuttua. Valtion ja paikallisen tason toimissa terveyden edistämisessä olisi oleellista selvittää, miten tieto muuttuu käytännöksi, mitkä ovat esteitä, miten ne voidaan poistaa.

Terveydenhuollon tutkimuksessa kohteita voisivat olla, miten terveyteen ja hyvinvointiin varatut resurssit kannattaisi jakaa ja miten tuo jako saadaan aikaiseksi. Tässä tärkeitä ovat yksityisten toimijoiden, etenkin yritysten rooli ja säätely teknologioiden arviointi mukaan lukien. Hyvän terveysjärjestelmän ja siinä olevien toimijoiden määrittely kaipaa myös tutkimusta avukseen. Henkilöstön tarvelaskelmat koulutuksen määrää varten tarvitaan.

Sosiaalilääketieteen eetoksen mukaisesti yhteiskunnallinen toiminta on tärkeätä tutkimuksen rinnalla. Mihin suuntaan sosiaalilääketieteen toimintaa tulisi painottaa? Tutkimusedellytysten ja alan opetuksen parantaminen ovat selviä kohteita. Lisäksi ajankohtaisten tapahtuminen seuraaminen ja tulevan ennakointi ovat tärkeitä. Tarvitaan verkostointia ja yhteydenpitoa kunkin asian suhteen samanmielisiin. Liittoutuminen muiden samaa asiaa ajavien tahojen kanssa mahdollistaa muutokset

Yhteiskunnallinen päätöksenteko on muuttunut vaikeammin hahmotettavaksi ja sen ymmärtäminen vaatii opiskelua. Yksi yhdistyksen painoalue voisi jatkossa olla, miten tehdä yhteiskunnallista vaikuttamista tehokkaasti. Sosiaalilääketiede ei ole vain lääketiedettä, mutta sen yhteiskunnallinen tuki on paljolti terveydenhuollossa. Terveydenhuollon rakenne ja säätely ovat oleellisia sosiaalilääketieteelle ja suunnitelmallinen, julkinen terveydenhuolto on sosiaalilääketieteen ystävä. 


\section{MAAILMA MUUTTUU TOISEKSI}

Toisen olettamukseni mukaan ilmaston lämpeneminen ja muut ympäristökysymykset muuttavat Suomen, Euroopan ja koko maailman täysin toiseksi. Halpa fossiilinen energia on mahdollistanut nykyisenkaltaisen tavan tuottaa tavaroita ja nykyisen elämäntyylin. Talouskasvu on ollut päämäärä ja tavaroiden valmistus ja myynti ovat olleet itseisarvoja - riippumatta niiden todellisesta tarpeesta. Tuotannon ja käytön ympäristövaikutuksille ei ole laitettu hintaa. Suomi ei ole isolaatiossa. Ilmasto ja sodat eivät katso rajoja ja Suomen elinkeinoelämä perustuu kansainväliseen kauppaan.

Jos halutaan estää lämpötilan nousu kriittisen rajan yläpuolelle, tulee kulutus, etenkin energian käyttö muuttaa nyt. Ennusteissa ei puhuta kaukaisesta tulevaisuudesta vaan lähiajasta. Vaatimus koskee kaikkia maita, mutta eri tavoin eri väestöryhmiä. Kulutus ei ole tasaisesti jakautunut: maailmanlaajuisesti pieni osa kuluttaa suurimman osan ja osan väestön kulutus on alle "oikean tason".

Suomen kohtuusliike-verkosto on julkaissut uusitut teesit "Kohtuulliset ilmastovaatimukset", miten ilmaston lämpenemistä tulee estää (4) (viite netistä). Seuraavassa muutama esimerkki antamaan kuvaa niistä: Teesi 1: Hiilen, öljyn, kaasun ja turpeen jättäminen maahan on selkein ja tehokkain tapa torjua haitallista ilmastonmuutosta. Teesi 3: Kaikilla tulee olla mahdollisuus irtautua ilmastoa vahingoittavasta palkkatyöstä tarjoamalla kaikille perustulo ja tukea työajan lyhentämiseen, uudelleenkoulutukseen ja omavaraistuotantoon. Teesi 5: Yhteistyössä maanviljelijöiden kanssa on siirryttävä agroekologian ja ilmastokestävyyden periaatteiden mukaiseen kasvispainotteiseen maatalouspolitiikkaan ja ruokajärjestelmään. Teesi 7: Turvallisuuspolitiikan painopiste tulee siirtää ilmastonmuutoksen torjuntaan ja voimavaroja siirtää mittavasti puolustusmenoista ilmastotoimiin.

Jos ilmastomuutoksen torjunta tehdään tehokkaasti, tulee suomalainenkin yhteiskunta olemaan erilainen kuin nyt. Halvan energian ja kaivannaisten kertakäytön lopettaminen muuttavat tuotantoa ja kulutusta. Nykyinen elinkeinoelämä ja ihmisten työt muuttuvat oleellisesti. Fyysisen ympäristön muuttuminen vaikuttaa kaikkeen sosiaaliseen ympäristöön, mm. varallisuuden jakaumaan, kauppaan, työhön ja sosiaalisiin suh- teisiin. Periaatteessa yhteiskunta sen jälkeen voisi olla tasa-arvoisempi ja terveyden kannalta parempi.

Mutta tehokkaaseen ilmaston torjuntaan ei välttämättä lähdetä. Luopuvatko instituutiot ja ihmiset vallastaan, varallisuudestaan ja eduistaan vapaaehtoisesti? Tapahtuuko se väkivallan kautta ja mitä se tarkoittaa massatuhoaseiden aikana? Biologi Katariina Vuorisen mukaan ihminen on lajina itsetuhoinen ja käyttäytyy niin kuin sopulipopulaatiot (5).

Useilla maailman alueilla luonnonolosuhteiden muuttuminen huonommaksi on todennäköistä ja monia alueita on jo merkitty vaaravyöhykkeeseen. Mutta myös Suomen luonnonolosuhteet voivat radikaalisti muuttua. Sään ääri-ilmiöiden lisääntymisen on liitetty ilmaston muutokseen. Olosuhteet maanviljelykseen voivat muuttua toisenlaiseksi vaatien uudenlaista maanviljelystä ja uudenlaisia työtapoja. Työpaikkojen ja työn tekemisen luonne voi muuttua oleellisesti ja sitä kautta ihmisten asumisen paikat ja liikenne.

Mikäli fyysiset elämisen ehdot, esimerkiksi kuivuuden, meren pinnan nousun, tulvien ja rajuilmojen vuoksi muuttuvat mahdottomiksi joillain alueilla, siitä seuraa monia asioita. Paikallinen ruoan ja veden puute voi johtaa kilpailuun maasta ja vedestä. Pakolaisuus ja siirtolaisuus lisääntyvät suurten joukkojen lähtiessä etsimään uutta asuinaluetta. Kansainvälinen työnjako ja tavarakauppa vähenevät. Toteutuessaan nämä muutokset vaikuttavat myös Suomeen ja osaltaan muuttavat työn, kaupan ja asumisen luonnetta.

Jos kaikki tämä tapahtuu rauhallisesti ja suunnitellusti, eläminen voi muuttua paremmaksi ihmisten voidessa tehdä mielekkäitä asioita. Mutta uhkana on eriarvoistuminen - lisääntynyt eriarvoisuus eri maiden ja väestöryhmien välillä. Kilpailu resursseista yhdessä muista välittämisen vähentymisen kanssa lisää riskiä konflikteihin ja väkivaltaan valtioiden sisällä ja välillä.

Jos yllä esittämäni ennustus ilmastonmuutoksesta on oikea, mitä sosiaalilääketieteilijöiden tulisi nyt Suomessa tehdä? Jos ja kun nämä surkeudet ympäristössä tapahtuvat, seuraamusten paikkauksessa on sosiaalilääketieteelle varmaan kysyntää. Minkälaisia valmiuksia tuleville tutkija- ja vaikuttajasukupolville tulisi tarjota ja mitä muutoksia tämä asettaa koulutukselle ja tiedon hankinnalle? Ne lienevät osittain erilaisia 
kuin tämän hetken valmiudet. Jussi Huttunen on jakanut viimeisen sadan vuoden aikana tapahtuneen terveyskehityksen kolmeen jaksoon (2). Ensimmäiselle jaksolle 1950-luvulle asti oli leimallista kehitys asuinoloissa, ravitsemuksessa ja hygieniassa. Palaako sosiaalilääketieteen painotus jälleen näihin teemoihin?

Mitä sosiaalilääketieteilijät voisivat tehdä estääkseen ilmastokatastrofin (paitsi kansalaisena toimimisen)? Pitäisikö nousta barrikadeille Rudolf Virchow'in ja Andrija Stampar'in hengessä? Vaatimattomampia esityksiä on seuraavassa. Olisi selkeästi esitettävä, että ilmaston ja muun ympäristön muutosten vaikutukset sosiaalisen yhteiskuntaan on myös sosiaalilääketieteellisen kysymys. Keskustelu ei sinällään muuta asioita, mutta se voi herättää toimijoita ja valmistaa hyväksyntää tuleville toimille. Omissa hankkeissa voisi miettiä mahdollisuutta, että maailma muuttuu ilmaston muutoksen vuoksi. Tiedon hankinnassa ovet ja ikkunat tulee pitää auki muualle maailmaan ja muihin tieteenaloihin. Verkostoituminen ja globaalien kehitysten ymmärtäminen tulevat entistä tärkeämmäksi. On varauduttava siihen, että muutokset eivät tapahdu sovinnollisesti ilman erityistoimia

Kannattaisiko SLY:kin perustaa työryhmä ilmaston muutoksen ehkäisyyn? Se voisi miettiä, miten mahdollisuus radikaalisti muuttuvaan ympäristöön pitäisi näkyä toiminnassa nyt ja tulevaisuudessa.

Artikkeli perustun Sosiaalilääketieteen päivillä 4.10.2018 pidettyyn pubeenvuoroon.

\section{LÄHTEET}

(1) Aukee R. Vanhasta uuteen sosiaalilääketieteeseen: suomalaisen sosiaalilääketieteen muotoutuminen 1800-luvun lopulta vuosituhannen vaihteeseen. Acta Universitatis Tamperensis 1825. Tampere: Tampere University Press; 2013.

(2) Lämsä R, Partanen V-M. Sosiaalilääketiede: mitä se on ja mihin menossa? Sosiaalilääk Aikak 2018; 55: 71-75.

https://doi.org/10.23990/sa.68988

(3) IPCC 2018. Global warming of $1.5^{\circ} \mathrm{C}$. An IPPC special report on the impacts of global warming of $1.5^{\circ} \mathrm{C}$ above pre-industrial levels and related global greenhouse gas emission pathways, in the context of strengthening the global response to the threat of climate change, sustainable development, and efforts to eradicate poverty summary for policymakers. WMO UNEP October 2018. http://www.ipcc.ch/

(4) Kymmenen kohtuullista ilmastovaatimusta. https://www.kohtuusliike.fi/. Ladattu 23.11.18

(5) Katajavuori M. Kuoleman ja elämän kysymys. Miten yksilöt, lajit ja yhteiskunnat altistavat itsensä tuholle. Jyväskylä: Atena; 2018.

\section{Elina Hemminki}

LKT, Kansanterveystieteen dosentti

Tutkimusprofessori emerita, Terveyden ja byvinvoinnin laitos 